TP Periodica Polytechnica Chemical Engineering

61(1), pp. 59-66, 2017

DOI: $10.3311 /$ PPch.10417

Creative Commons Attribution (i)

RESEARCH ARTICLE

\section{Aminated Single-walled Carbon Nanotubes as Carrier for Covalent Immobilization of Phenylalanine Ammonia-lyase}

\author{
Judith Hajnal Bartha-Vári ${ }^{1}$, László Csaba Bencze ${ }^{1}$, Evelin Bell ${ }^{2}$, \\ László Poppe ${ }^{1,2,3}$, Gabriel Katona ${ }^{1}$, Florin-Dan Irimie ${ }^{1}$, \\ Csaba Paizs ${ }^{1}$, Monica Ioana Toşa ${ }^{1 *}$
}

Received 16 December 2016; accepted after revision 29 December 2016

\begin{abstract}
A new and efficient immobilized form of phenylalanine ammonia-lyase (PAL) was obtained by covalent linkage onto amino functionalized single-walled carbon nanotubes $\left(\mathrm{SwCNT} \mathrm{N}_{\mathrm{NH} 2}\right)$ as carrier. The catalytic properties of the resulted nanostructured biocatalyst ( $\mathrm{SwCNT} \mathrm{NH}_{2}-\mathrm{PAL}$ ) were tested in the kinetic resolution of racemic 2-amino-3-(thiophen-2-yl)propanoic acid 1 by ammonia elimination and in the enantiotope selective addition of ammonia onto (E)-3-(thiophen-2-yl)acrylic acid 2. SwCNT $T_{\mathrm{NH}_{2}}-\mathrm{PAL}$ was a durable biocatalyst in batch mode for ammonia elimination from 1 (>85\% of original activity after 7 cycles) and in ammonia addition to 2 (>70\% of original activity after 3 cycles in $6 \mathrm{M} \mathrm{NH}_{3}, \mathrm{pH} \mathrm{10.0)}$. The ammonia addition onto 2 was also studied in a continuous-flow microreactor packed with $\mathrm{SwCNT}_{\mathrm{NH}_{2}}$-PAL (2 $\left.\mathrm{MNH}_{3}, \mathrm{pH} 10.0,15 \mathrm{bar}\right)$ in the 30-80 ${ }^{\circ} \mathrm{C}$ temperature range. No significant loss of PAL activity was observed over $72 h$ in the microreactor up to $60{ }^{\circ} \mathrm{C}$. Productivity of $\mathrm{SwCNT} \mathrm{NH}_{2}-\mathrm{PAL}$ at $30{ }^{\circ} \mathrm{C}$ was significantly higher in the enantiotope selective ammonia addition performed in a packed-bed reactor operated in continuousflow mode $\left(r_{\text {flow }}=2.41 \mathrm{mmol} \mathrm{min}^{-1} \mathrm{~g}^{-1}\right)$ than in the reaction performed in batch system $\left(r_{\text {batch }}=1.38 \mathrm{mmol} \mathrm{min}^{-1} \mathrm{~g}^{-1}\right)$.
\end{abstract}

\section{Keywords}

$P A L$, aminated SwCNT, covalent immobilization, continuousflow system

\footnotetext{
${ }^{1}$ Biocatalysis and Biotransformation Research Center, Babeş-Bolyai University of Cluj-Napoca

Arany János str. 11, Ro-400028 Cluj-Napoca, Romania

${ }^{2}$ Department of Organic Chemistry and Technology, Budapest University of Technology and Economics, H-1521 Budapest, P.O.B. 91, Hungary

${ }^{2}$ SynBiocat LLC,

H-1024 Budapest, Lövőház utca 19/1, Hungary

*Corresponding author, e-mail: mtosa@chem.ubbcluj.ro
}

\section{Introduction}

Biocatalysis is a resource efficient, economical, energy saving, and environment-friendly way to perform synthetic processes [1]. Since the biocatalyst is often dissolved in the reaction medium, separation and reuse of the catalyst may be difficult [2]. Immobilization of the biocatalysts offers a solution to enhance the properties of these catalysts for synthesis of fine chemicals and pharmaceuticals [3], for food modification or energy production [4]. Immobilization of the enzymes can overcome the major drawbacks of enzyme application, such as the lack of long-term operational stability and the difficulty of the enzyme recovery [5]. Enzyme immobilization can be achieved by binding to a solid support, cross-linking or entrapment [6]. Covalent coupling to a solid support is the most typical way of immobilizing enzymes [7].

The unique properties of carbon nanotubes attracted attention due to their potential applications [8]. The use of carbon nanotubes ranges from large scale structures in automobiles to nanometer scale electronics [9]. Carbon nanotubes are used primarily in composites [10], but also in tensile strength fibers and fire resistant materials [11]. Due to their unique structural, mechanical, electrical, electrochemical properties there is an increasing interest in their biological applications [12], mainly as nanocarriers for proteins aiming to develop efficient biosensors. Carbon nanotubes are widely used for the immobilization of biomacromolecules, exploiting their mechanical, thermal, electrical properties and general biocompatibility [13].

Ammonia-lyases, acting on $\mathrm{C}-\mathrm{N}$ bonds, catalyze the formation of $\alpha, \beta$-unsaturated bonds by elimination of ammonia from their substrates [14]. Several ammonia-lyases ware applied in the stereoselective synthesis of enantiopure $\alpha$-amino acids such as L-phenylalanine or $(S)$-2-chlorophenylanine by addition of ammonia to $(E)$-cinnamic acid [15], or $(E)-2$ chlorocinnamic acid [16]. PAL can be also used in medicine, as enzyme replacement treating the phenylketonuria [17], or even in cancer treatment [18]. The synthetic potential of PAL has been utilized in production of PAL immobilized on carbon nanotubes [19] or on magnetic nanoparticles [20-21] which had been successfully used in microfluidic reactors 
for stereoselective biotransformation. Application of immobilized enzymes in miniaturized or microfluidic reactors for biotransformations offers multiple advantages such as higher efficiency of the process and improved operational stability of the biocatalysts [22, 23].

In our previous study [19], phenylalanine ammonia-lyase from Petroselinum crispum (PcPAL) was immobilized by covalent linkage onto carboxylated single-walled carbon nanotubes $\left(\mathrm{SwCNT}_{\mathrm{COOH}}\right)$ to prepare $\mathrm{PcPAL}$ biocatalysts with improved properties for continuous-flow applications. In this study we performed the covalent immobilization of the same enzyme on aminated single walled carbon nanotubes $\left(\mathrm{SwCNT}_{\mathrm{NH} 2}\right)$ with the aim to further improve the enzyme stability for the ammonia addition reaction. The $\mathrm{SwCNT}_{\mathrm{NH}_{2}}-\mathrm{PAL}$ obtained in this way was tested as biocatalyst for stereoselective biotransformations, both in batch mode and in continuous-flow reactors.

\section{Materials and Methods}

\subsection{Materials}

\subsubsection{Enzyme}

Phenylalanine ammonia-lyase from parsley (Petroselinum crispum, PcPAL) was obtained after overexpression in E. coli and purification using a previously reported protocol [14].

\subsubsection{Chemicals}

Synthesis of the racemic 2-amino-3-(tiophen-2-yl)propionic acid (1) and 3-(tiophen-2-yl)acrylic acid (2) was performed starting from the corresponding aldehyde by known methods $[24,25]$. Single-wall carbon nanotubes (SwCNT; ID = 0.8-1.6 nm, OD 1-2 nm, Length $=5-30 \mu \mathrm{m}$ ) were purchased from Chengdu Organic Chemicals Co. Ltd (Chengdu, China). Glycerol diglycidyl ether (GDE), Bradford reagent for protein determination, tris(hydroxymethyl)-aminomethane (TRIS), sodium phosphate and $\left[\mathrm{D}_{4}\right]$-acetic acid were purchased from Sigma-Aldrich (St. Luis, MO, USA). Technical grade solvents such as methanol and dichloromethane were dried and/or freshly distilled prior to use.

\subsubsection{Equipment}

Transmission electron microscopy (TEM) was performed using an automatic H-7650 TEM, Hitachi (Tokyo, Japan) with accelerating voltage 40-120 kV, zoom 200x-600000x, by dipping a holey-carbon TEM grid into a suspension of the immobilized enzyme. Sample was imaged in the TEM operating at $120 \mathrm{kV}$ using an Olympus KeenView G2 camera.

Elemental analyses were carried out with a Vario Micro Cube analyzer, Elementer Analysensysteme GmBH (Langeselbold, Germany).

The quantitative protein assay based on Bradford method was performed on an Agilent $8453 \mathrm{UV}-\mathrm{Vis}$ spectrophotometer (Santa Clara, CA, USA).
The enzymatic reactions in batch mode were shaken in a Titramax 1000 instrument.

For ultrasonication a Transsonic 460/H ultrasonic bath, Elma Schmidbauer GmbH (Singen, Germany), operated at $100 \mathrm{~W}, 40 \mathrm{kHz}$ was used.

The conversions for batch reactions were calculated using the ${ }^{1} \mathrm{H}$-NMR spectra in $\left[\mathrm{D}_{4}\right]$-acetic acid as solvent at $25{ }^{\circ} \mathrm{C}$, recorded on Ascend 400 or Ascend 600 NMR spectrometers, Bruker (Karlsruhe, Germany) operating at 400 and $600 \mathrm{MHz}$, respectively [19].

The amination reaction of the single-walled carbon nanotubes was performed at $600 \mathrm{~W}$ power at 50 bar pressure, $300{ }^{\circ} \mathrm{C}$ for $1 \mathrm{~h}$ in a CEM Microwave-assisted Reactor, CEM Corporation (Matthews, USA).

SwCNTs were filtered on a PTFE membrane filter with $0.22 \mu \mathrm{m}$ pore size, Membrane-solutions, Nantong Co., Ltd. (Sanghai, China).

\subsection{Methods}

\subsubsection{Functionalization of SwCNT with amino groups}

The functionalization of carbon nanotubes was carried out using a modified method by Mirzarakhmetova et al. [26]. The reaction mixture contained SwCNT (400 mg), urea (400 mg) and dimethyl formamide (DMF, $5 \mathrm{~mL}$ ). The reaction was carried out in a microwave assisted reactor at $300{ }^{\circ} \mathrm{C}$ for $1 \mathrm{~h}$. After the reaction the modified SwCNT was washed with DMF, methanol, $\mathrm{CH}_{2} \mathrm{Cl}_{2}$, and dried. Elemental analysis data shown an $\sim 4.8 \% \mathrm{NH}_{2}$ content for the aminated single walled carbon nanotubes $\left(\mathrm{SwCNT}_{\mathrm{NH} 2}\right)$. According to TEM analysis, the geometry of the parent SwCNT (ID = 0.8-1.6 nm, OD 1-2 nm, Length $=5-30 \mu \mathrm{m})$ did not changed significantly by amine functionalization.

\subsubsection{Covalent binding of PcPAL onto SwCNT ${ }_{\mathrm{NH} 2}$}

$\mathrm{SwCNT}_{\mathrm{NH} 2}(20 \mathrm{mg})$ was incubated with a solution of glycerol diglycidyl ether (GDE, $32.4 \mathrm{mg}, 0.2 \mathrm{mmol}$ ) in $\mathrm{CH}_{2} \mathrm{Cl}_{2}$ $(5 \mathrm{~mL})$ under shaking at $1350 \mathrm{rpm}$ at room temperature overnight, with occasional sonication to avoid bundled SwCNT formation (Fig. 1, step $i$ ). The sample was filtered on a membrane filter and then washed with $\mathrm{CH}_{2} \mathrm{Cl}_{2}(3 \times 1 \mathrm{~mL})$. To the resulted modified $\mathrm{SwCNT}_{\mathrm{NH} 2}$, a solution of PcPAL $(2.0 \mathrm{mg}$ in $1 \mathrm{~mL}$ of $0.1 \mathrm{M}$ Tris buffer, $\mathrm{pH} 8.8$ ) was added and the mixture was shaken at room temperature at $1350 \mathrm{rpm}$, overnight (Fig. 1, step ii). The formed biocatalyst was filtered off on a membrane filter and washed with distilled water $(3 \times 10 \mathrm{~mL})$. The amount of immobilized PcPAL was determined by comparison of the mass of PcPAL in the solution before the immobilization (2.0 mg in $1 \mathrm{~mL}$ solution) and after immobilization ( $0.06 \mathrm{mg}$, in the unified filtrates) by spectrophotometric assay using the Bradford method. 


\subsubsection{Ammonia elimination from 1 catalyzed by $\mathrm{SwCNTNH}_{2}-\mathrm{PAL}$}

Into the solution of racemic 2-amino-3-(thiophen-2-yl)propanoic acid $(\mathbf{1}, 4.7 \mu \mathrm{mol}, 0.8 \mathrm{mg})$ in Tris buffer $(1 \mathrm{~mL}, 0.1 \mathrm{M}$, $\mathrm{pH}$ 8.8) was added $\mathrm{SwCNT}_{\mathrm{NH}_{2}}$-PAL biocatalyst (6 mg).

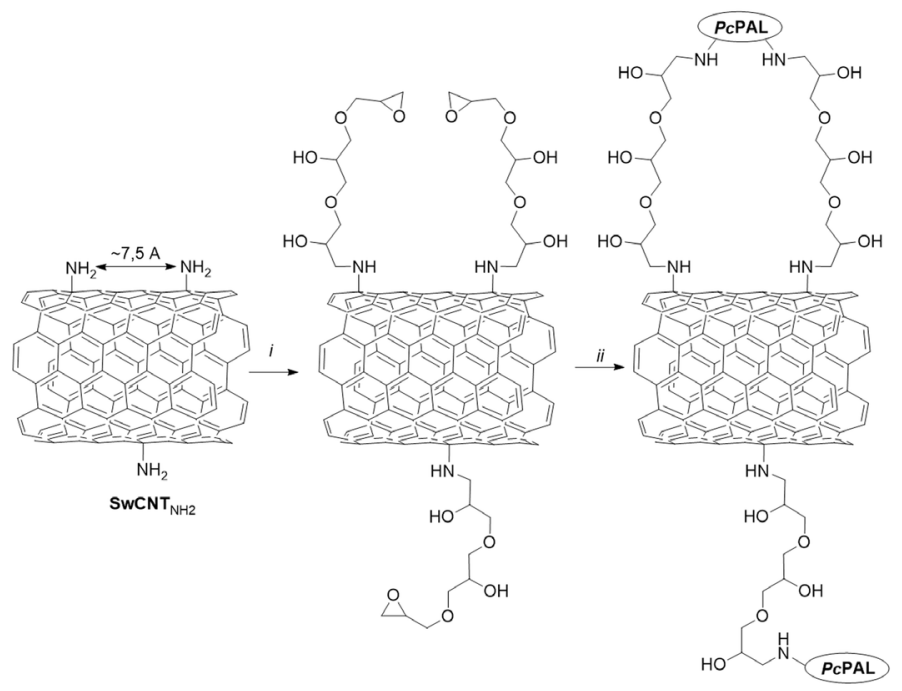

Fig. 1 Immobilization of PAL on SwCNT $\mathrm{NH}_{2}$ : i) $\mathrm{GDE}$ in $\mathrm{CH}_{2} \mathrm{Cl}_{2}$; ii) PAL in Tris buffer (0.1 M Tris buffer, $\mathrm{pH} 8.8)$

After preforming the reaction at room temperature for $17 \mathrm{~h}$ under shaking $(1250 \mathrm{rpm})$, the reaction mixture was filtered on a membrane filter and the filtrate was concentrated. ${ }^{1} \mathrm{H}-\mathrm{NMR}$ spectra of the residue, after removal of the solvent, were recorded and used to calculate conversions as previously reported [19]. The recovered $\mathrm{SwCNT}_{\mathrm{NH} 2}-\mathrm{PAL}$ was washed with Tris buffer ( $1 \mathrm{~mL}, 0.1 \mathrm{M}, \mathrm{pH} 8.8)$ and after filtration it was reused under the same reaction conditions.

\subsubsection{Ammonia addition to 2 with SwCNTNH ${ }_{2}-\mathrm{PAL}$ in batch mode}

Into the solution of 3-(thiophen-2-yl)acrylic acid (2, $4.5 \mu \mathrm{mol}, 0.7 \mathrm{mg})$ in ammonia solution $(2 \mathrm{M}, 1 \mathrm{~mL}$, $\mathrm{pH}$ set to 10 with $\left.\mathrm{CO}_{2}\right)$, the $\mathrm{SwCNT}_{\mathrm{NH}_{2}}$-PAL biocatalyst $(6 \mathrm{mg})$ was added and the reaction was performed for $17 \mathrm{~h}$ at room temperature under shaking $(1350 \mathrm{rpm})$. The reaction mixture was filtered and the filtrate was concentrated. ${ }^{1} \mathrm{H}-\mathrm{NMR}$ spectra of the residue, after removal of the solvent, were recorded and used to calculate conversions as previously reported [19]. Before reuse under the same reaction conditions, the recovered $\mathrm{SwCNT}_{\mathrm{NH}_{2}}$-PAL was washed with Tris buffer $(1 \mathrm{~mL}$, $0.1 \mathrm{M}, \mathrm{pH} 8.8$ ), conditioned by shaking for $2 \mathrm{~h}$ in phosphate buffer $(1 \mathrm{~mL}, 0.1 \mathrm{M}, \mathrm{pH}=6)$ and washed with Tris buffer (1 mL, 0.1 M, pH 8.8) again.

\subsubsection{Ammonia addition to 3-(thiophen-2-yl)-acrylic acid 2 with SwCNT ${ }_{\mathrm{NH}_{2}}-\mathrm{PAL}$ in continuous-flow packed-bed microreactor}

The continuous-flow experiments were performed in a thermostated SynBioCart microreactor $(30 \mathrm{~mm} \times 3 \mathrm{~mm}$ ID PTFE SynBioCart columns filled with $110 \mathrm{mg}$ of $\mathrm{SwCNT}_{\mathrm{NH}_{2}}-\mathrm{PAL}$ in a PEEK SynBioCart column holder closed with PTFE membrane filter of $0.22 \mu \mathrm{m}$ pore size) attached to the pump module of an Agilent LC 1150 HPLC system and a back-pressure regulator valve (VICI AG, JR-BPR1). Prior to perform the reaction, the microreactor was washed with $2 \mathrm{M}$ ammonia solution ( $\mathrm{pH}$ set to 10 with $\mathrm{CO}_{2}$ ) at $0.5 \mathrm{~mL} \mathrm{~min}^{-1}$ flow rate for $20 \mathrm{~min}$.

The experiments were performed by pumping the solution of 3-(thiophen-2-yl)acrylic acid (2, $4.5 \mathrm{mM})$ in $2 \mathrm{M}$ ammonia solution ( $\mathrm{pH}$ set to 10 with $\mathrm{CO}_{2}$ ) through the thermostated $\mathrm{SwCNT}_{\mathrm{NH} 2}$-PAL-filled column at various temperatures (25-

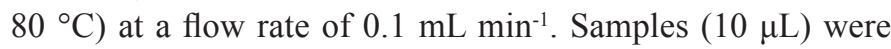
withdrawn at every $10 \mathrm{~min}$ (after reaching the stationary state, usually $30 \mathrm{~min}$ ) and analyzed by an UV spectrophotometer (added to $990 \mu \mathrm{L}$ of $2 \mathrm{M}$ ammonia solution, at $290 \mathrm{~nm}$ ). The experiments at room temperature $\left(25^{\circ} \mathrm{C}\right)$ were conducted without backpressure regulation, the experiments between 30 and $80{ }^{\circ} \mathrm{C}$ were performed with backpressure (set to 15 bar).

All experiments were performed with the same $\mathrm{SwCNT}_{\mathrm{NH}^{2}}{ }^{-}$ PAL-filled column in the temperature range $25-60{ }^{\circ} \mathrm{C}$. Intermittently, the immobilized PAL-filled column was stored at $4{ }^{\circ} \mathrm{C}$ (after washing with distilled water, at $0.5 \mathrm{~mL} \mathrm{~min}^{-1}$ for $30 \mathrm{~min}$ ). In tests above $60{ }^{\circ} \mathrm{C}$, new $\mathrm{SwCNT}_{\mathrm{NH} 2}-\mathrm{PAL}-$ filled columns were used at each temperature.

\section{Results and Discussion}

The aim of this study was to create covalently immobilized PAL biocatalyst with even higher activity and reusability in the ammonia addition reaction onto arylacrylates than was observed for $\mathrm{SwCNT}_{\mathrm{COOH}^{-}}-\mathrm{PAL}$ [19]. To achieve this goal SwCNT was functionalized first with amino groups to give a support $\left(\mathrm{SwCNT}_{\mathrm{NH} 2}\right)$ suitable for direct bisepoxide-functionalization and subsequent covalent attachment of PcPAL $\left(\mathrm{SwCNT}_{\mathrm{NH} 2}\right.$, see Fig. 1). According to our estimation assuming zig-zag conformation for the linkers, the resulted linker in $\mathrm{SwCNT}_{\mathrm{NH} 2}-\mathrm{PcPAL}$ was about $0.7 \mathrm{~nm}$ shorter than the previously applied linker in $\mathrm{SwCNT}_{\mathrm{COOH}}$-PAL [19]. Furthermore, this shorter linker was expected to be more stable because it did not contain hydrolysable amide bond. The catalytic properties of the resulted novel immobilized form of PcPAL ( $\mathrm{SwCNT}_{\mathrm{NH}_{2}}-\mathrm{PAL}$ ) were evaluated in the ammonia elimination from 2-amino-3-(thiophen-2-yl) propanoic acid $\mathbf{1}$ and in the ammonia addition onto 3-(thiophen-2-yl)acrylic acid $\mathbf{2}$ as test reactions (Fig. 3 and Table 1). 


\subsection{Covalent immobilization of PcPAL onto $\mathrm{SwCNT}_{\mathrm{NH} 2}$}

The method applied for covalent attachment of PcPAL onto $\mathrm{SwCNT}_{\mathrm{COOH}}[19]$ was simplified for the covalent immobilization of the enzyme onto functionalized $\mathrm{SwCNT}_{\mathrm{NH} 2}$. First, $\mathrm{SwCNT}_{\mathrm{NH} 2}$ was activated by reaction with a large excess of glycerol diglycidyl ether (GDE), followed by attachment of $P c$ PAL onto the surface of $\mathrm{SwCNT}_{\mathrm{NH} 2}$ via the GDE-based linker (Fig. 1). Immobilization yield $(97 \pm 1.5 \%$ of the PcPAL was bound to the bisepoxide-activated $\mathrm{SwCNT}_{\mathrm{NH} 2}$ resulting in $88 \mu \mathrm{g}$ protein/mg biocatalyst) as well as the stability of covalently immobilized enzyme (Fig. 2 showing TEM data before and after 12 cycles) were high and reproducible.

A

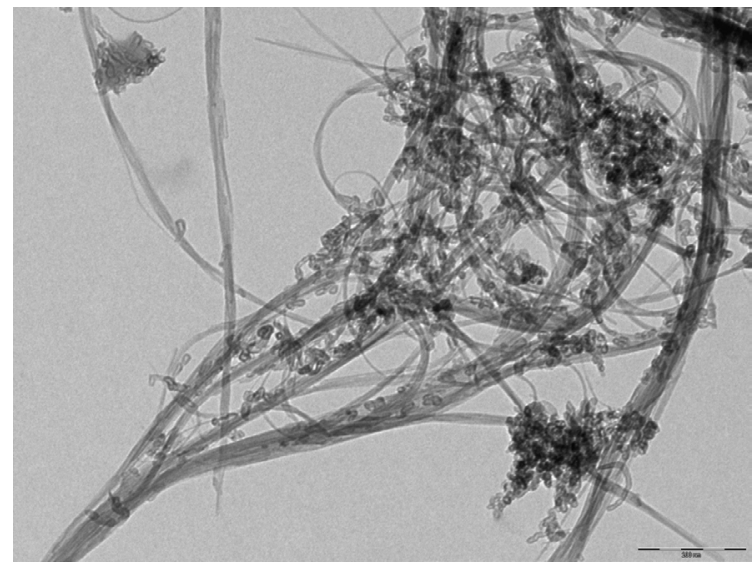

B

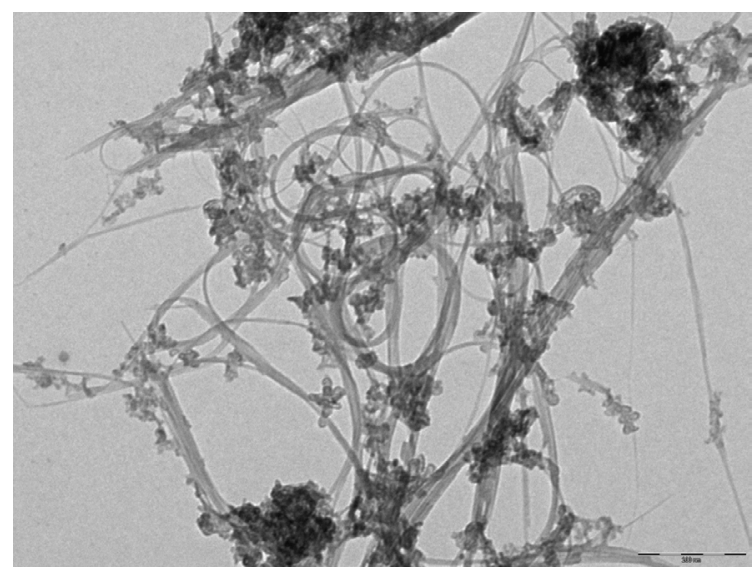

Fig. 2 TEM images of $\mathrm{SwCNT}_{\mathrm{NH} 2}$-PAL (A) before and (B) after 12 cycles of ammonia addition onto $2(4.5 \mathrm{mM})$ in $2 \mathrm{M}$ ammonia ( $\mathrm{pH} 10.0)$. Length of the scale bars is $200 \mathrm{~nm}$.

\subsection{Biocatalytic behavior of $\mathrm{SwCNT}_{\mathrm{NH} 2}-\mathrm{PAL}$ in stereoselective biotransformations of 2-amino-3- (thiophen-2-yl) propanoic acid 1 and 3-(thiophen- 2-yl)acrylic acid 2 in batch mode}

The novel $\mathrm{SwCNT}_{\mathrm{NH2}}$-PAL preparation was tested as biocatalyst at room temperature in the ammonia elimination from 2-amino-3-(thiophen-2-yl)propanoic acid $\mathbf{1}$ and in the ammonia addition to 3-(thiophen-2-yl)acrylic acid 2 performed in batch mode (Fig. 3).

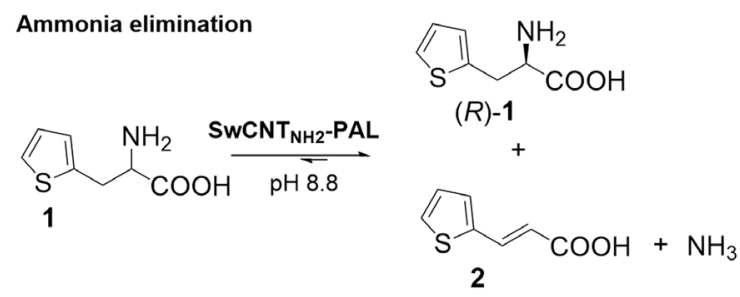

Ammonia addition

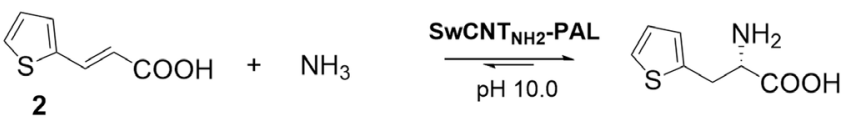

Fig. $3 \mathrm{SwCNT}_{\mathrm{NH}_{2}}$-PAL for ammonia elimination from 2-amino-3-(thiophen2-yl)propanoic acid $\mathbf{1}$ and ammonia addition to 3-(thiophen-2-yl)acrylic acid $\mathbf{2}$

The kinetic resolution of the racemic 1 catalyzed by $\mathrm{SwCNT}_{\mathrm{NH} 2}-\mathrm{PAL}$ occurred with high conversions (close to the theoretically possible $50 \%$ conversion). Moreover, the biocatalyst retained most of its initial activity and could be reused several times (Table 1).

Table 1 Conversion of the reactions catalyzed by the immobilized PcPAL on aminated $\mathrm{SwCNT}_{\mathrm{NH} 2}\left(25^{\circ} \mathrm{C}, 17 \mathrm{~h}\right)$

\begin{tabular}{lll}
\hline \multirow{2}{*}{ Run } & \multicolumn{2}{c}{ Conversion (\%) } \\
\cline { 2 - 3 } & Addition to 2 & Elimination from 1 \\
\hline 1 & 63.9 & 49.6 \\
2 & 63.5 & 48.5 \\
3 & 64.2 & 48.8 \\
4 & 63.8 & 47.4 \\
5 & 60.0 & 46.3 \\
7 & 49.2 & 42.4 \\
\hline
\end{tabular}

In the case of ammonia addition to 2 requiring much harsher conditions (6 M ammonia, $\mathrm{pH} 10$ ) the new $\mathrm{SwCNT}_{\mathrm{NH} 2}-\mathrm{PAL}$ form was significantly more active $(64.2 \%$ conversion, see Table 1$)$ than $\mathrm{SwCNT}_{\mathrm{COOH}^{-}} \mathrm{PAL}$ (36.9\% conversion [19]). Moreover, $\mathrm{SwCNT}_{\mathrm{NH} 2}-\mathrm{PAL}$ was also much more durable, losing more than $80 \%$ of its original activity only after 6 cycles (Table 1), in contrast to $\mathrm{SwCNT}_{\mathrm{COOH}^{-}}-\mathrm{PAL}$ which inactivated completely after 3 cycles [19]. In ammonia solutions the enhanced durability of $\mathrm{SwCNT}_{\mathrm{NH}_{2}}-\mathrm{PAL}$ compared to $\mathrm{SwCNT}_{\mathrm{COOH}^{-}}-\mathrm{PAL}$ was expected because the linker of $\mathrm{SwCNT}_{\mathrm{NH} 2}-\mathrm{PAL}$ contained non-hydrolyzable ether and alkylamine bonds besides the C-C bonds. Contrarily, it was indicated that an amide bond - being present in the linker of $\mathrm{SwCNT}_{\mathrm{COOH}}-\mathrm{PAL}$ - could undergo hydrolysis under various conditions [27] or transamidation with other amines even under mild conditions by enzyme catalysis [28].

As it was known that ammonia addition onto arylacrylates can be performed at lower ammonia concentrations $[19,29]$, the 
reaction was tested with 2 in $3 \mathrm{M}$ and $2 \mathrm{M}$ ammonia solutions as well. At the lower ammonia concentrations $\mathrm{SwCNT}_{\mathrm{NH} 2}-\mathrm{PAL}$ exhibited significantly higher stability (Fig. 4). In $2 \mathrm{M}$ ammonia at $\mathrm{pH} 10$, more than $82 \%$ of the initial activity was retained even after 12 cycles.

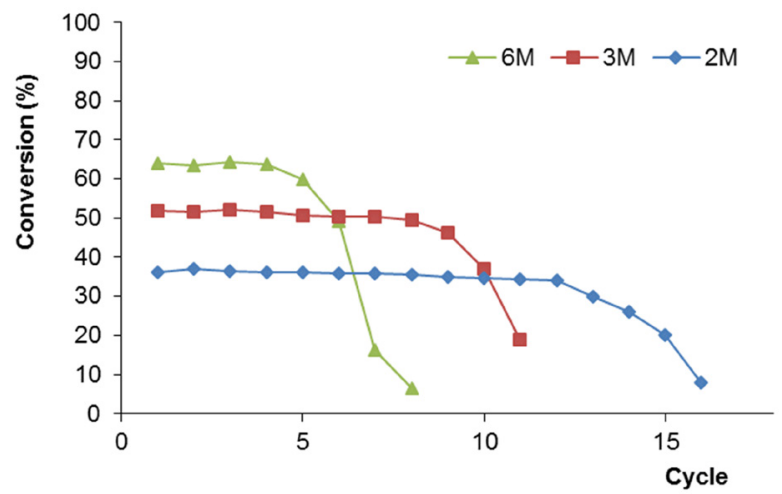

Fig. 4 Recyclability of $\mathrm{SwCNT}_{\mathrm{NH}_{2}}$-PAL in ammonia addition reaction to 3-(thiophen-2-yl)acrylic acid $2(4.5 \mathrm{mM})$ in batch mode at various ammonia concentrations ( $2 \mathrm{M}, 3 \mathrm{M}$ and $\left.6 \mathrm{M} ; \mathrm{pH} 10.0 ; 25^{\circ} \mathrm{C}, 17 \mathrm{~h}\right)$.

The unusual shape of the inactivation curves in recycling study with a plateau followed by rapid inactivation (Fig. 4) initiated a hypothesis. It could be assumed that at high concentration of ammonia, the small $\mathrm{NH}_{3}$ molecules penetrated gradually into the protein and replaced the structural water. Further, it could be assumed that such replacements happened at first in the region close to the surface of the enzyme which resulted in non-detrimental changes in the PcPAL structure. The rapid deactivation happened when deeper penetration of $\mathrm{NH}_{3}$ molecules into the enzyme destroyed the active structure.

Thus, it could be assumed that penetration of ammonia into the surface layer of protein might be reversed by conditioning the enzyme in slightly acidic medium. This possibility was tested in the recycling of $\mathrm{SwCNT}_{\mathrm{NH}_{2}}$-PAL from $6 \mathrm{M}$ ammonia medium used for ammonia addition to 2 (Fig. 5). Thus, in order to regain the activity and increase the durability of the immobilized PcPAL the biocatalyst was washed and kept in phosphate buffer $(\mathrm{pH}=6)$ for $2 \mathrm{~h}$ at room temperature under shaking at $1250 \mathrm{rpm}$ when the enzyme's apparent deactivation was observed. Because the enzyme regained its initial activity for the ammonia addition reaction to 2 the initial hypothesis has been validated (Fig. 5).

Based on these results, a modified washing/reconditioning protocol was applied for recycling of $\mathrm{SwCNT}_{\mathrm{NH} 2}-\mathrm{PAL}$ from $6 \mathrm{M}$ ammonia medium ( $\mathrm{pH}=10)$. The modified protocol involved acidic reconditioning after each ammonia addition reaction as described above. In this way the enzyme preserved more than $90 \%$ of its initial activity even after 25 cycles (Fig. 6). This means at least five-fold durability enhancement [from five cycles (see Fig. 4) to at least 25 cycles (Fig. 6)].

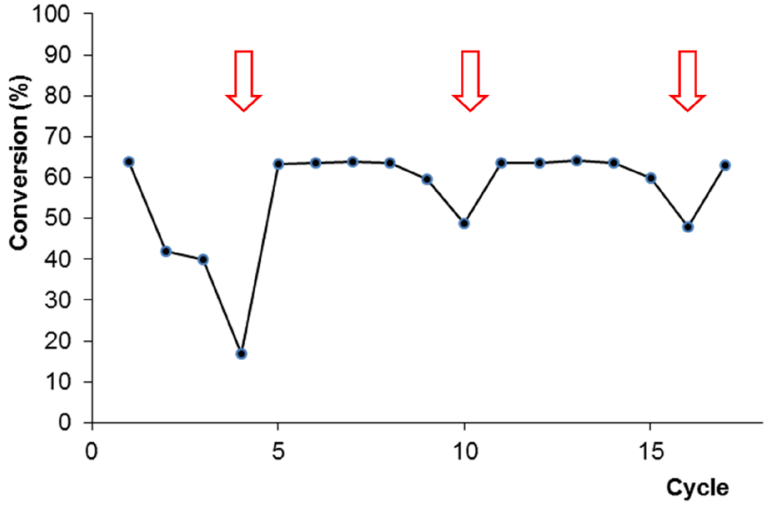

Fig. 5 Repeated ammonia addition reactions to 3-(thiophen-2-yl)acrylic acid 2 (4.5 mM, in $6 \mathrm{M}$ ammonia; $\mathrm{pH} 10.0 ; 25^{\circ} \mathrm{C}, 17 \mathrm{~h}$ ) including washing of $\mathrm{SwCNT}_{\mathrm{NH} 2}$-PAL with phosphate buffer $(\mathrm{pH} 6)$ when the apparent inactivation is observed (indicated by the red arrows).

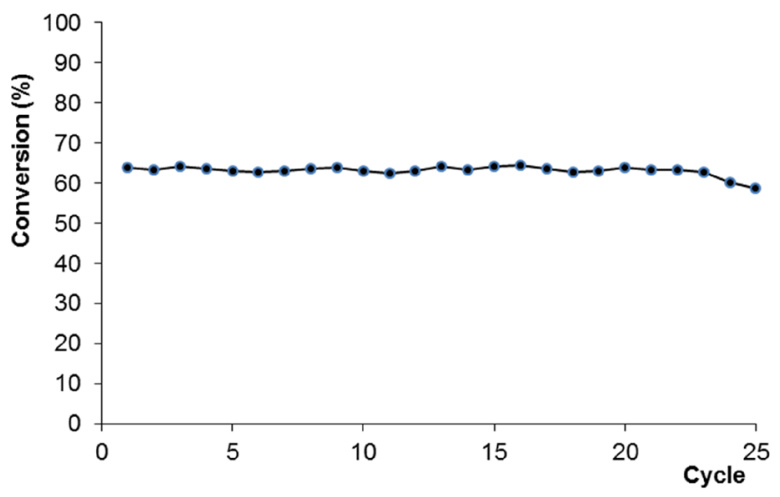

Fig. 6 Repeated ammonia addition reactions to 3-(thiophen-2-yl)acrylic acid 2 (4.5 mM, in $6 \mathrm{M}$ ammonia; $\mathrm{pH} 10.0 ; 25^{\circ} \mathrm{C}, 17 \mathrm{~h}$ ), including washing of $\mathrm{SwCNT}_{\mathrm{NH} 2}-\mathrm{PAL}$ with phosphate buffer $(\mathrm{pH} 6)$ after each reaction

\subsection{Investigation of the ammonia addition reaction to 3-(thiophen-2-yl)acrylic acid 2 catalyzed by $\mathrm{SWCNT}_{\mathrm{NH} 2}-\mathrm{PAL}$ in a continuous-flow packed-bed microreactor}

A further way of process intensification is the application of the biocatalysts in continuous-flow microreactors [30]. Application of continuous-flow microreactors can significantly enhance the operational stability of immobilized biocatalysts [23]. Thus, ammonia addition to $\mathbf{2}$ was studied in a biocompatible, $\mathrm{SwCNT}_{\mathrm{NH} 2}$-PAL-packed-bed PTFE microreactor column (SynBioCart) operated in continuous-flow mode (Fig. 7). The continuous-flow system comprised the biocatalyst-filled microreactor in the column thermostat of a HPLC system equipped with a back-pressure regulator.

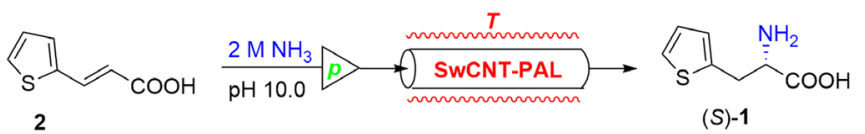

Fig. 7 Ammonia addition to 3-(thiophen-2-yl)acrylic acid 2 in a continuousflow packed-bed microreactor 
Our previous study with $\mathrm{SwCNT}_{\mathrm{COOH}-}$ PAL-filled continuousflow microreactor indicated that application of proper backpressure (15 bar) was necessary to avoid apparent enzyme activity loss due to bubble formation [19]. Thus, in this study all experiments above room temperature were performed with back-pressure regulation (15 bar).

To evaluate the degree of activity enhancement of $\mathrm{SwCNT}_{\mathrm{NH} 2}-\mathrm{PAL}$ in the ammonia addition reaction to $\mathbf{2}$ the specific reaction rate of the biotransformation was determined at $30^{\circ} \mathrm{C}$ in continuous-flow and in batch modes as defined by Eq. (1) and Eq. (2), respectively [30],

$$
\begin{gathered}
r_{\text {flow }}=\frac{[P] \times f}{m_{e}} \\
r_{\text {batch }}=\frac{n_{P}}{\left(t \times m_{e}\right)}
\end{gathered}
$$

where $r_{\text {flow }}$ : specific reaction rate in a continuous-flow reactor; $[P]$ : product concentration $\left(\mu \mathrm{mol} \mathrm{mL} \mathrm{m}^{-1}\right), f$ : flow rate $\left(\mathrm{mL} \mathrm{min}^{-1}\right)$, $m_{e}$ : mass of immobilized biocatalyst (g); and $r_{\text {batch }}$ : specific reaction rate in a shake or stirred batch system, $n_{p}$ : amount of the product ( $\mu \mathrm{mol}), t$ : the reaction time ( $\mathrm{min})$.

The specific reaction rate is an applicable measure to compare the biocatalyst's productivity under various conditions. For a comparison between the productivity of an immobilized biocatalyst in a continuous-flow reaction and in the same reaction in batch mode, the specific reaction rates should be investigated at the same degree of conversions since the rate of product formation is not a linear function of conversions [30]. The conversion of $64 \%$ (being far enough from the $>90 \%$ equilibrium conversion [24]) was chosen for comparison of the batch and of the continuous-flow mode ammonia addition reactions to 2 catalyzed by $\mathrm{SwCNT}_{\mathrm{NH} 2}$-PAL in $2 \mathrm{M}$ ammonia ( $\mathrm{pH} 10$, at $30^{\circ} \mathrm{C}$ ). As expected, the specific reaction rate in the continuous-flow reactor $\left(r_{\text {flow }}=2.63 \mu \mathrm{mol} \mathrm{min} \mathrm{m}^{-1} \mathrm{~g}^{-1}\right)$ was significantly higher than

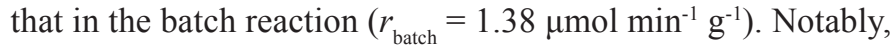
the specific reaction rate for $\mathrm{SwCNT}_{\mathrm{NH}_{2}}$-PAL in the continuousflow reactor was also higher than for $\mathrm{SwCNT}_{\mathrm{NH} 2}-\mathrm{PAL}$ under

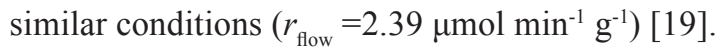

The enhanced stability and higher specific activity of $\mathrm{SwCNT}_{\mathrm{NH} 2}$-PAL compared to the previously studied

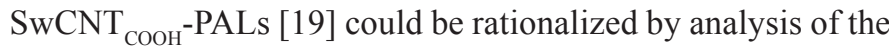
functional group density of the two carriers. From the weight proportion of $\mathrm{NH}_{2}(4.8 \mathrm{w} / \mathrm{w} \%)$ in $\mathrm{SwCNT}_{\mathrm{NH} 2}$ an average distance of $0.75 \mathrm{~nm}$ could be calculated between the amino functions on the surface of $\mathrm{SwCNT}_{\mathrm{NH} 2}$ (Fig. 1). Considering the elongated spheroid shape of homotetrameric PcPAL with axes of $\sim 8.5 \mathrm{~nm}$ and $\sim 17 \mathrm{~nm}$, there is a high possibility of multipoint fixation of the enzyme onto the GDE-treated $\mathrm{SwCNT}_{\mathrm{NH} 2}$.
It is known that multipoint covalent attachment can stabilize the immobilized enzymes [31, 32]. Moreover, it was demonstrated that multipoint attachment could enhance the operational stability of immobilized enzymes in microfluidic reactor as well [33].

Thus, the six-fold lower surface density of the carboxylate functions could be calculated for the carboxylated carbon nanotube used as basic carrier for $\mathrm{SwCNT}_{\mathrm{COOH}}$-PALs [19], which results in much lower possibility of multipoint fixation as compared to $\mathrm{SwCNT}_{\mathrm{NH} 2}-\mathrm{PAL}$ in the present study. Moreover, the linkers are $\sim 0.8 \mathrm{~nm}$ shorter in $\mathrm{SwCNT}_{\mathrm{NH}_{2}}$-PAL as the ones

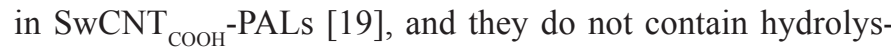
able functional groups like the amide bond within the linkers of $\mathrm{SwCNT}_{\mathrm{COOH}^{-}}$-PALs. This may also contribute to the enhanced durability of PcPAL in the novel $\mathrm{SwCNT}_{\mathrm{NH}_{2}}$ PAL biocatalyst.

The temperature dependence of the $\mathrm{SwCNT}_{\mathrm{NH} 2}-\mathrm{PAL}-$ catalyzed continuous-flow mode ammonia addition to 2 in $2 \mathrm{M}$ ammonia ( $\mathrm{pH} 10$ ) in the $30-80{ }^{\circ} \mathrm{C}$ range was quite similar, to that of $\mathrm{SwCNT}_{\mathrm{COOH}^{-}}$-PAL [19]. A local minimum of the initial conversion was observed at $50{ }^{\circ} \mathrm{C}$ (Fig. 8) with significantly lower conversion than at $40^{\circ} \mathrm{C}$ or even at $30{ }^{\circ} \mathrm{C}$.

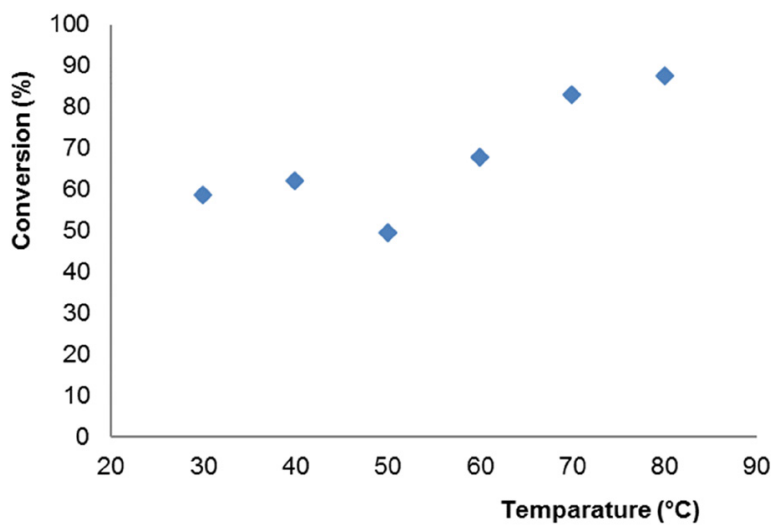

Fig. 8 Temperature effect on the ammonia addition reaction to $2(4.5 \mathrm{mM})$ in a continuous-flow microreactor (in $2 \mathrm{M}$ ammonia, $\mathrm{pH} 10,30^{\circ} \mathrm{C}$ )

The long term operational stability study of the $\mathrm{SwCNT}_{\mathrm{NH}_{2}-}$ PAL was studied in the continuous-flow mode ammonia addition to 2 in $2 \mathrm{M}$ ammonia ( $\mathrm{pH} 10$ ) in the $30-80{ }^{\circ} \mathrm{C}$ temperature range (Fig. 9). This study indicated that at $50{ }^{\circ} \mathrm{C}$ and $60{ }^{\circ} \mathrm{C}$ the activity of $\mathrm{SwCNT}_{\mathrm{NH} 2}$-PAL remained stable over $72 \mathrm{~h}$ and was higher than those obtained between $30{ }^{\circ} \mathrm{C}$ and $50{ }^{\circ} \mathrm{C}$. Thus, the apparent decrease of the activity of $\mathrm{SwCNT}_{\mathrm{NH} 2}-\mathrm{PAL}$ at $50{ }^{\circ} \mathrm{C}$ cannot be attributed to irreversible thermal inactivation. At $70{ }^{\circ} \mathrm{C}$ and $80{ }^{\circ} \mathrm{C}$ however, while the initial activity of the biocatalyst increased with temperature, the enzyme inactivated rapidly and irreversibly. 


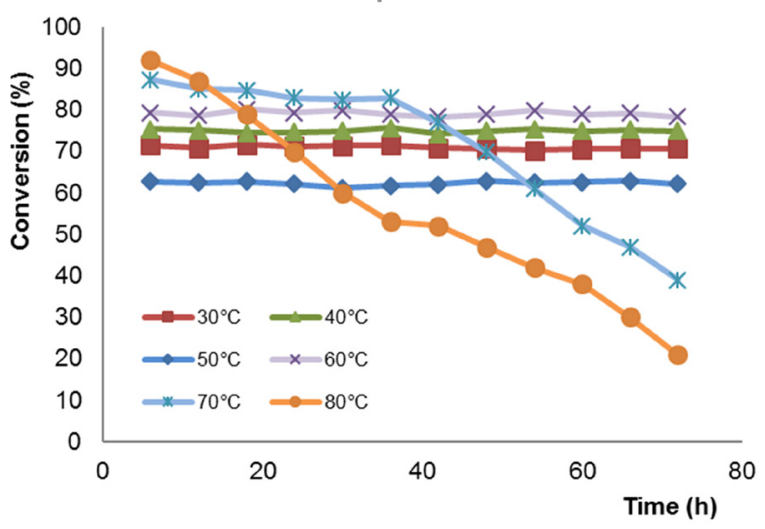

Fig. 9 Temperature effect on the long term stability in ammonia addition to 3-(thiophen-2-yl)acrylic acid $2\left(4.5 \mathrm{mM}, 2 \mathrm{M}\right.$ ammonia, $\left.\mathrm{pH} 10,30{ }^{\circ} \mathrm{C}\right)$

\section{Conclusions}

In this study, covalent immobilization of phenylalanine ammonia-lyase from Petroselinum crispum (PcPAL) on amine -functionalized single-walled carbon nanotubes $\left(\mathrm{SwCNT}_{\mathrm{NH} 2}\right)$ was achieved. The novel immobilized form of PcPAL $\left(\mathrm{SwCNT}_{\mathrm{NH} 2}-\mathrm{PAL}\right)$ was applicable for the synthesis of $(R)-2-$ amino-3-(thiophen-2-yl)propanoic acid $(R)$-1 by kinetic resolution of the corresponding racemate as well as of its enantiomer (S)-1 by enantiotope selective ammonia addition to the achiral 3-(thiophen-2-yl)acrylic acid 2. By applying glycerol diglycidyl ether (GDE)-activated $\mathrm{SwCNT}_{\mathrm{NH} 2}$ as support material, the resulted $\mathrm{SwCNT}_{\mathrm{NH} 2}-\mathrm{PAL}$ biocatalyst showed higher activity in the ammonia addition reaction to 2 then the previously reported $P c$ PAL form immobilized on carboxy functionalized nanotubes ( $\left.\mathrm{SwCNT}_{\mathrm{NH} 2}-\mathrm{PALs}\right)$ and could be reused more times. Further stability enhancement could be achieved by conditioning the immobilized PAL biocatalyst in a slightly acidic buffer (phosphate, $\mathrm{pH}$ 6) for several hours during recycling. In this way, $\mathrm{SwCNT}_{\mathrm{NH} 2}$-PALs retained more than $90 \%$ of its initial activity even after 25 cycles. When tested in a packed-bed continuous flow microreactor, the $\mathrm{SwCNT}_{\mathrm{NH} 2}-\mathrm{PAL}$ was stable in the ammonia addition reaction to 2 , with its initial activity being fully maintained for $72 \mathrm{~h}$ at $60{ }^{\circ} \mathrm{C}$.

The main factors leading to the enhanced stability are the higher linker density in $\mathrm{SwCNT}_{\mathrm{NH} 2}-\mathrm{PAL}$ as compared to $\mathrm{SWCNT}_{\mathrm{NH} 2}$-PALs resulting in higher probability of multipoint enzyme fixation and the absence of hydrolysable functions in the linkers.

\section{Acknowledgement}

Financial support for project NEMSyB, ID P37_273, Cod MySMIS 103413 funded by the Romanian Ministry for European Funds, through the National Authority for Scientific Research and Innovation (ANCSI) and co-funded by the European Regional Development Fund, Competitiveness Operational Program 2014-2020 (POC), Priority axis 1, Action 1.1 is gratefully acknowledged. LCB thanks for the financial support from the Romanian National Authority for Scientific Research and Innovation, CNCS-UEFISCDI, project number PN-II-RU-TE-2014-4-1668. LP and CP thank the support from COST Action CM1303 (SysBiocat).

\section{References}

[1] Wohlgemuth, R. "Biocatalysis - key to sustainable industrial chemistry." Current Opinion in Biotechnology. 21, pp. 713-724. 2010. https://doi.org/10.1016/j.copbio.2010.09.016

[2] Hanefeld, U., Gardossi, L., Magner, E. "Understanding enzyme immobilisation." Chemical Society Reviews. 38, pp. 453-468. 2009. https://doi.org/10.1039/B711564B

[3] Cantone, S., Ferrario, V., Corici, L., Ebert, C., Fattor, D., Spizzo, P., Gardossi, L. "Efficient immobilisation of industrial biocatalysts: criteria and constraints for the selection of organic polymeric carriers and immobilisation methods." Chemical Society Reviews. 42, pp. 6262-6276, 2013. https://doi.org/10.1039/c3cs35464d

[4] Rodrigues, R. C., Ortiz, C., Berenguer-Murcia, A., Torres, R., FernandezLafuente, R. "Modifying enzyme activity and selectivity by immobilization." Chemical Society Reviews. 42, pp. 6290-6307. 2013.

https://doi.org/10.1039/c2cs35231a

[5] Sheldon, R. A., van Pelt, S. "Enzyme immobilisation in biocatalysis: why, what and how." Chemical Society Reviews. 42, pp. 6223-6235. 2013. https://doi.org/10.1039/C3CS60075K

[6] Franssen, M. C. R., Steunenberg, P., Scott, E. L., Zuilhofac, H., Sanders, J. P. M. "Immobilised enzymes in biorenewables production." Chemical Society Reviews. 42, pp. 6491-6533. 2013.

https://doi.org/10.1039/c3cs00004d

[7] Adlercreutz, P. "Immobilisation and application of lipases in organic media." Chemical Society Reviews. 42, pp. 6406-6436. 2013. https://doi.org/10.1039/C3CS35446F

[8] Banerjee, S., Hemraj-Benny, T., Wong, S. S. "Covalent surface chemistry of single-walled carbon nanotubes." Advanced Materials. 17, pp. 17-29. 2005. https://doi.org/10.1002/adma.200401340

[9] Bandaru, P. R. "Electrical Properties and Applications of Carbon Nanotube Structures." Journal of Nanoscience and Nanotechnology. 7, pp. 1-29. 2007. https://doi.org/10.1166/jnn.2007.307

[10] Gustavsson, P., Hedmer, M., Rissler, J. "Carbon nanotubes - Exposure, toxicology and protective measures in the work environment." (Kunskapsöversikt; Vol. Rapport 2011:1) Lund University, Lund, Sweeden, 2013. lup.lub.lu.se/record/2295102/file/2300375.pdf

[11] Rummeli, M. H., Ayala, P., Pichler, T. "Carbon Nanotubes and Related Structures: Production and Formation." In: Carbon Nanotubes and Related Structures. (Guldi, D. M., Martín, N. (eds.)) Chapter 1, WileyVCH Verlag GmbH \& Co. KGaA, Weinheim, Germany, 2010. https://doi.org/10.1002/9783527629930.ch1

[12] Lee, H. K., Lee, J. K., Kim, M. J., Lee, J. C. "Immobilization of Lipase on Single Walled Carbon Nanotubes in Ionic Liquid." Bulletin of the Korean Chemical Society. 31, pp. 650-652. 2010. https://doi.org/10.5012/bkcs.2010.31.03.650

[13] Pavlidis, I. V., Vorhaben, T., Tsoufis, T., Rudolf, T. P., Bornscheuer, U. T., Gournis, D., Stamatis, H. "Development of effective nanobiocatalytic systems through the immobilization of hydrolases on functionalized carbon-based nanomaterials." Bioresource Technology. 115, pp. 164-171. 2012. https://doi.org/10.1016/j.biortech.2011.11.007

[14] Poppe, L., Paizs, C., Kovács, K., Irimie, F. D., Vértessy, B. G. "Preparation of Unnatural Amino Acids with Ammonia-Lyases and 2,3-Aminomutases." Methods in Molecular Biology. 794, pp. 3-19. 2012. https://doi.org/10.1007/978-1-61779-331-8_1 
[15] Hamilton, B. K., Hsiao, H. Y., Swann, W. E., Anderson, D. M., Delent, J. J. "Manufacture of L-amino acids with bioreactors." Trends in Biotechnology. 3, pp. 64-68. 1985.

https://doi.org/10.1016/0167-7799(85)90079-4

[16] de Lange, B., Hyett, D. J., Maas, P. J. D., Mink, D., van Assema, F. B. J., Sereinig, N., de Vries, A. H. M., de Vries, J. G. "Asymmetric Synthesis of (S)-2-Indoline-carboxylic Acid by Combining Biocatalysis and Homogeneous Catalysis." ChemCatChem. 3, pp. 289-292. 2011. https://doi.org/10.1002/cctc.201000435

[17] Wang, L., Gamez, A., Archer, H., Abola, E. E., Sarkissian, C. N., Fitzpatrick, P., Wendt, D., Zhang, Y., Vellard, M., Bliesath, J., Bell, S. M., Lemontt, J. F., Scriver, C. R., Stevens, R. C. "Structural and Biochemical Characterization of the Therapeutic Anabaena variabilis Phenylalanine Ammonia Lyase." Journal of Molecular Biology. 38, pp. 623-335. 2008. https://doi.org/10.1016/j.jmb.2008.05.025

[18] Babich, O. O., Pokrovsky, V. S., Anisimova, N. Y., Sokolov, N. N., Prosekov, A. Y. "Recombinant L-phenylalanine ammonia lyase from Rhodosporidium toruloides as a potential anticancer agent." Biotechnology and Applied Biochemistry. 60, pp. 316-322. 2013. https://doi.org/10.1002/bab.1089

[19] Bartha-Vári, J.H., Tosa, M. I., Irimie, F. D., Weiser, D., Boros, Z., Vértessy, B. G., Paizs, C., Poppe, L. "Immobilization of phenylalanine ammonia-lyase on single-walled carbon nanotubes for stereoselective biotransformation in batch and continuous-flow modes." Chem CatChem, 7, pp. 1122-1128. 2015. https://doi.org/10.1002/cctc.201402894

[20] Weiser, D., Bencze, L.C., Bánóczi, G., Ender, F., Kiss, R., Kókai, E., Szilágyi, A., Vértessy, B.G., Farkas, O., Paizs, C., Poppe, L. "Phenylalanine Ammonia-Lyase-Catalyzed Deamination of an Acyclic Amino Acid: Enzyme Mechanistic Studies Aided by a Novel Microreactor Filled with Magnetic Nanoparticles." ChemBioChem. 16, pp. 2283-2288. 2015. https://doi.org/10.1002/cbic.201500444

[21] Ender, F., Weiser, D., Nagy, B., Bencze, L. C., Paizs, C., Palovics, P., Poppe, L. "Microfluidic multiple cell chip reactor filled with enzymecoated magnetic nanoparticles - An efficient and flexible novel tool for enzyme catalyzed biotransformations." Journal of Flow Chemistry. 6(1), pp. 43-52. 2016. https://doi.org/10.1556/1846.2015.00036

[22] Wohlgemuth, R., Plazl, I., Žnidaršič-Plazl, P., Gernaey, K., Woodley, J. "Microscale technology and biocatalytic processes: Opportunities and challenges for synthesis." Trends in Biotechnology. 33(5), pp. 302-314. 2015. https://doi.org/10.1016/j.tibtech.2015.02.010

[23] Bajić, M., Plazl, I., Stloukal, R., Žnidaršič-Plazl, P. "Development of a miniaturized packed bed reactor with $\omega$-transaminase immobilized in LentiKats." Process Biochemistry. 52, pp. 63-72. 2017. https://doi.org/10.1016/j.procbio.2016.09.021
[24] Paizs, C., Katona, A., Rétey, J. "The Interaction of Heteroaryl-Acrylates and Alanines with Phenylalanine Ammonia-Lyase from Parsley." Chemistry-A European Journal. 12, pp. 2739-2744. 2006.

https://doi.org/10.1002/chem.200501034

[25] Paizs, C., Katona, A., Rétey, J. "Chemoenzymatic One-Pot Synthesis of Enantiopure L-Arylalanines from Arylaldehydes." European Journal of Organic Chemistry. 5, pp. 1113-1116, 2006.

https://doi.org/10.1002/ejoc.200500902

[26] Mirzarakhmetova, D. T., Dekhkonov, D. B., Rakhimov, M. M., Abdurazakova, S. Kh., Akhmedova, Z. R. "The Properties of Invertase, Covalently Immobilized at Activated Carbon." Applied Biochemistry and Microbiology. 3, pp. 258-261. 2009.

https://doi.org/10.1134/S000368380903003X

[27] Khan, M. N. "Experimental versus theoretical evidence for the ratelimiting steps in uncatalyzed and $\mathrm{H}^{+}$- and $\mathrm{HO}^{-}$catalyzed hydrolysis of the amide bond." International Journal of Chemical Kinetics. 41(9), pp. 599-611. 2009. https://doi.org/10.1002/kin.20435

[28] Sergeeva, M. V., Mozhaev, V. V., Rich, J. O., Khmelnitsky, Y. L. "Lipasecatalyzed transamidation of non-activated amides in organic solvent." Biotechnology Letters. 22(17), pp. 1419-1422. 2000. https://doi.org/10.1023/A:1005621117392

[29] Kovács, K., Bánóczi, G., Varga, A., Szabó, I., Holczinger, A., Hornyánszky, G., Zagyva, I., Paizs, C., Vértessy, B. G., Poppe, L. "Expression and Properties of the Highly Alkalophilic Phenylalanine Ammonia-Lyase of Thermophilic Rubrobacter xylanophilus." PLoS ONE. 9(1), e85943, 2014. https://doi.org/10.1371/journal.pone.0085943

[30] Csajági, C., Szatzker, G., Tőke, E. R., Ürge, L., Darvas, F., Poppe, L., "Enantiomer selective acylation of racemic alcohols by lipases in continuous-flow bioreactors." Tetrahedron: Asymmetry. 19(2), pp. 237-246. 2008. https://doi.org/10.1016/j.tetasy.2008.01.002

[31] Mateo, C., Abian, O., Fernandez-Lafuente, R., Guisan, J. M. "Increase in conformational stability of enzymes immobilized on epoxy-activated supports by favoring additional multipoint covalent attachment." Enzyme and Microbial Technology. 26(7), pp. 509-515. 2000.

https://doi.org/10.1016/S0141-0229(99)00188-X

[32] Mateo, C., Grazu, V., Palomo, J. M., Lopez-Gallego, F., FernandezLafuente, R., Guisan J. M. "Immobilization of enzymes on heterofunctional epoxy supports." Nature Protocols. 2, pp. 1022-1033. 2007. https://doi.org/10.1038/nprot.2007.133

[33] Valikhani, D., Bolivar, J. M., Pfeiffer, M., Nidetzky, B. "Multivalency Effects on the Immobilization of Sucrose Phosphorylase in Flow Microchannels and Their Use in the Development of a High-Performance Biocatalytic Microreactor." ChemCatChem. 2016. https://doi.org/10.1002/cctc.201601019 